\title{
Characterizing Sphingosine Kinases and Sphingosine 1-Phosphate Receptors in the Mammalian Eye and Retina
}

\author{
Hunter Porter ${ }^{1, \dagger}$, Hui Qi ${ }^{1,+}$, Nicole Prabhu ${ }^{1,+}$, Richard Grambergs ${ }^{2}$, Joel McRae ${ }^{1}$, \\ Blake Hopiavuori ${ }^{1}$ and Nawajes Mandal ${ }^{1,2, *}$ \\ 1 Department of Ophthalmology, University of Oklahoma Health Sciences Center, \\ Oklahoma City, OK 73104, USA; hunter-porter@OUHSC.edu (H.P.); hui-qi@OUHSC.edu (H.Q.); \\ nicole-prabhu@OUHSC.edu (N.P.); joel-mcrae@OUHSC.edu (J.M.); blake-hopiavuori@OUHSC.edu (B.H.) \\ 2 Departments of Ophthalmology, Anatomy and Neurobiology, University of Tennessee Health Sciences \\ Center, Memphis, TN 38163, USA; rgramber@uthsc.edu \\ * Correspondence: nmandal@UTHSC.edu; +1-901-448-7740 \\ + Equally contributing author.
}

Received: 19 November 2018; Accepted: 27 November 2018; Published: 5 December 2018

\begin{abstract}
Sphingosine 1-phosphate (S1P) signaling regulates numerous biological processes including neurogenesis, inflammation and neovascularization. However, little is known about the role of S1P signaling in the eye. In this study, we characterize two sphingosine kinases (SPHK1 and SPHK2), which phosphorylate sphingosine to S1P, and three S1P receptors (S1PR1, S1PR2 and S1PR3) in mouse and rat eyes. We evaluated sphingosine kinase and S1P receptor gene expression at the mRNA level in various rat tissues and rat retinas exposed to light-damage, whole mouse eyes, specific eye structures, and in developing retinas. Furthermore, we determined the localization of sphingosine kinases and S1P receptors in whole rat eyes by immunohistochemistry. Our results unveiled unique expression profiles for both sphingosine kinases and each receptor in ocular tissues. Furthermore, these kinases and S1P receptors are expressed in mammalian retinal cells and the expression of SPHK1, S1PR2 and S1PR3 increased immediately after light damage, which suggests a function in apoptosis and/or light stress responses in the eye. These findings have numerous implications for understanding the role of S1P signaling in the mechanisms of ocular diseases such as retinal inflammatory and degenerative diseases, neovascular eye diseases, glaucoma and corneal diseases.
\end{abstract}

Keywords: S1P; sphingosine 1-phosphate; S1PR1; sphingosine 1-phosphate receptor 1; S1PR2; S1PR3; sphingosine kinase 1; SPHK2; retina; eye

\section{Introduction}

Sphingolipids play diverse roles in the biology of cells and tissues [1]. As structural lipids, they are essential to maintaining membrane fluidity and organizing lipid rafts [2,3]. However, their role is far from limited to membrane dynamics. The various species of sphingolipids are found throughout the cell including in the nucleus, cytoplasm, and in the extracellular space as signaling molecules [3-6]. Bioactive sphingolipids such as sphingosine 1-phosphate (S1P) and ceramide (Cer) are now recognized as important mediators of many basic cellular processes including cell migration, survival, contraction, proliferation, gene expression and various cell-cell interactions [1,5,7-15]. The scope of the sphingolipid system's impact on mammalian biology has proven to be impressive due to the complexity of the "sphingolipid rheostat" and the many signaling pathways that sphingolipids are involved in.

The sphingolipid rheostat is comprised of dozens of enzymes that constantly shift concentrations of sphingolipids such as sphingomyelin (SM), Cer and sphingosine (Sph) by metabolizing them into 
other sphingolipid species. Ceramides and S1P are potent signaling molecules, which the sphingolipid rheostat can generate to respond to a stimulus or use as intermediates toward the degradation pathway. S1P is generated from sphingosine by sphingosine kinases 1 and 2 (SPHK1/SPHK2). Mice deficient in both SPHK1 and SPHK2 have many vascular and neuronal deficits during the development and are not viable past E13.5 [16]. SPHK1 and SPHK2 single knockout animals generally have no phenotype and are thought to compensate with the remaining kinase. However, knocking out SPHK2 is sufficient to reduce resilience to oxygen-induced retinopathy [17]. Meanwhile, the S1P produced by the two kinases has shown myriad roles in retinal development and function. S1P has shown to be essential for photoreceptor development [18] and Muller glia migration [19]. After development, modulating S1P has shown benefits in preventing immune cell migration and neovascularization after insult.

The biological effects of S1P are largely attributed to its high-affinity association with receptors present on various cell types. S1P receptors are divided into five subgroups (S1PR1-5), which are G-protein-coupled receptors with unique expression patterns and roles in cell signaling [20-24]. S1PR1 is the most well studied and is present on endothelial cells, B-cells and T-cells. S1PR1 is also an essential receptor for influencing blood vessel development and maturation $[21,25,26]$. S1PR1 knockout animals are nonviable. S1PR2 and 3 are also ubiquitously expressed [20-24] and important for proper vascular development [27,28]. S1PR2 is important for cell migration [29] and S1PR2 mutations induce hearing loss by disrupting endocochlear potential gradients [30]. S1PR3 has demonstrated an important role in a bacterial infection response [31], nociception and itching sensation [32]. S1PR4 and S1PR5 expression is more restricted and they are mostly found on the cells of the immune and nervous systems, respectively [33,34]. S1PR4 is essential to differentiation of dendritic cells [35] and is important to immune cell chemoattraction [36]. S1PR5 is important in cell migration and, by selectively modulating its activity, can ameliorate demyelination [37] and alter the integrity of the blood brain barrier [38]. In summary, S1P receptors are essential for immune cell response modulation, cell migration, and vascular development and maintenance. These functions are critical to retinal development and survival, but their role in the eye is poorly understood.

In the eye, S1P can protect neural cells from apoptosis by inhibiting synthesis of its precursor ceramide, which is a pro-death signaling molecule [5,39-43]. We have previously shown that targeting S1P receptors with FTY-720, which is marketed as a drug for multiple sclerosis, can delay retinal degeneration in light damage and genetic models [44,45]. Ocular tissues outside the retina such as the cornea and retinal pigment epithelium (RPE) have shown S1P receptor expression with functions important to controlling fibrotic responses [46]. Modulating the S1P receptor signaling with FTY-720 has also shown to be beneficial in ocular autoimmune conditions such as uveitis [47]. In the retina proper, S1P is critical to photoreceptor development [18], axonal guidance [48] and survival of retinal ganglion cells in glaucoma [49]. Given the numerous effects of S1P receptors showing translation into ocular development and pathology, we have identified a critical need to understand the distributions of both S1P receptors and sphingosine kinases in the eye. As S1P receptor modulation has shown benefits in counteracting retinal degeneration, we also studied how the expression of S1P-producing sphingosine kinases and S1P receptors changes over time in cases of retinal damage induced by intense light stress. Characterizing S1P signaling in ocular development and stress responses will deepen our understanding of eye health and diseases and potentially identify novel pathways for therapeutic intervention.

\section{Results}

\subsection{Distribution and Expression of Sphingosine Kinase (Sphk) and Sphingosine 1-Phosphate Receptor (S1pr)} mRNA in Rat Tissue

To understand the roles of S1P signaling in the eye, we first explored the expression of relevant protein coding transcripts throughout the body. Using qRT-PCR, we assayed the expression and distribution of S1P-producing enzymes and the major S1P receptors in various tissues from adult SD rats. SPHK2 is corroborated as a major S1P-producing enzyme with high expression across all 
assayed tissues. At the same time, SPHK1 was expressed primarily in ovary and kidney tissue with minimal expression in most other tissues-notably the brain and retina (Figure 1A). S1pr1 was highly expressed in the hindbrain, moderately expressed in the forebrain, retina, heart, lungs and spleen, and minimally expressed in the liver, skin and testes. S1pr3 was moderately expressed in the forebrain, retina, liver, heart, lungs, testes and kidney and in retinal pigment epithelium-choroid (RPE-choroid) tissue. S1pr2 and S1pr5 showed minimal expression in the tissues analyzed (Figure 1B).

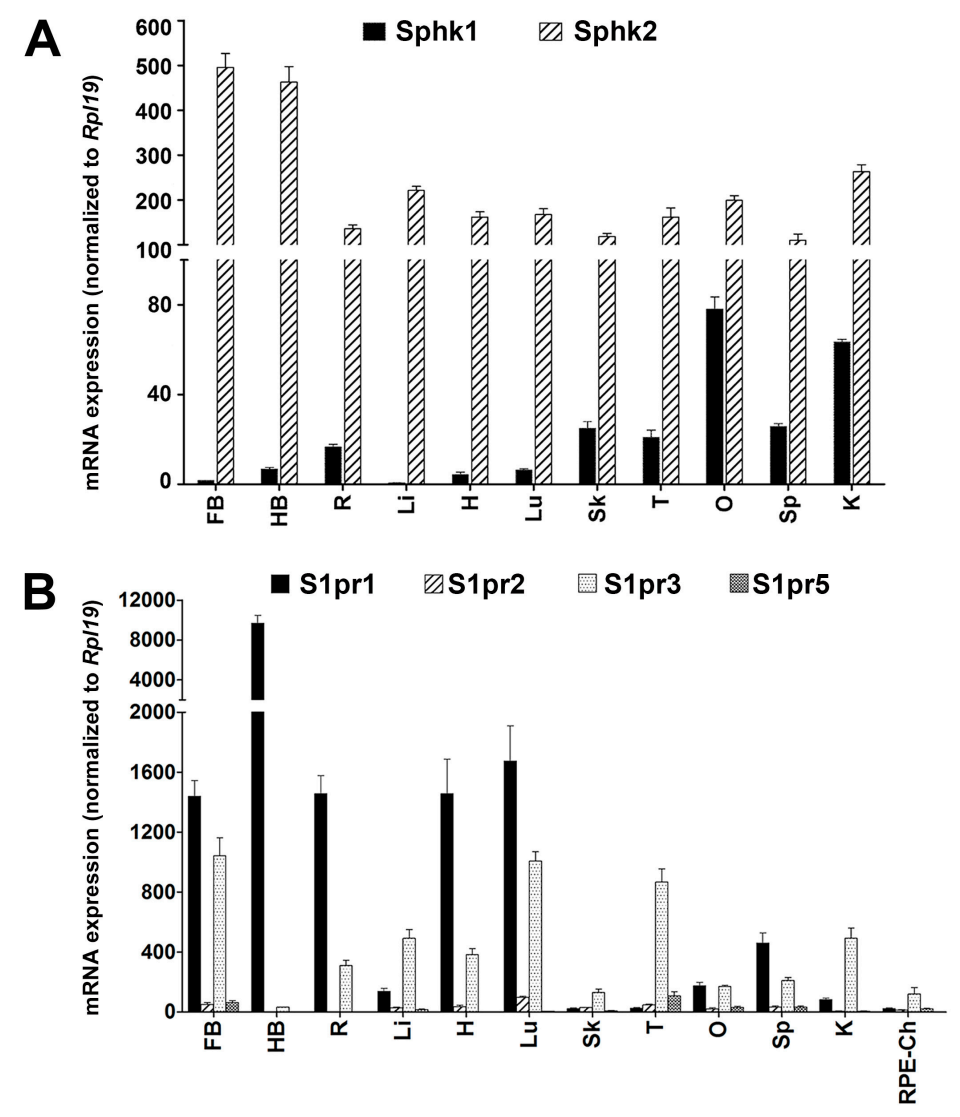

Figure 1. The expression and distribution of sphingosine kinases and S1P receptors in adult (2-7 months old) SD rat tissues. For each feature, the mean of three independent qRT-PCR experiments $( \pm \mathrm{SE})$ is shown and normalized to the expression of the ribosomal protein Rpl19. (A) Sphingosine kinase (Sphk) 1 and 2 mRNA expression in the tissue. (B) Sphingosine 1-phosphate receptor (S1pr) 1, 2, 3 and 5 mRNA expression in tissue. FB, forebrain. $\mathrm{HB}$, hindbrain. $\mathrm{R}$, retina. Li, liver. $\mathrm{H}$, heart. Lu, lung. Sk, skin. T, testes. O, ovary. Sp, spleen. K, kidney. RPE-Ch, retinal pigment epithelium-choroids.

\subsection{Distribution and Expression of Sphingosine Kinase and Major S1P Receptor mRNA in Mouse Eye Tissues}

Next, we determined the expression and distribution of Sphk1 and Sphk2 as well as the major S1P receptors S1pr1, S1pr2 and S1pr3 in various mouse eye tissues. RNA was prepared from cleanly dissected mouse cornea, lens, iris-ciliary body, optic nerve, eye cups and retina, as described previously [50-52]. Using qRT-PCR, we observed high expression of Sphk2 throughout the cornea, iris/ciliary body, optic nerve, eye cup and retina while Sphk1 expression was minimal in all ocular tissues and highest in the retina and optic nerve (Figure 2A), which reflects our previous findings in rat tissue. We observed high expression of S1pr1 mRNA in mouse retinas, which is also in line with our prior findings, and noted high S1pr1 expression in the iris/ciliary body, optic nerve and eye cups (Figure 2B). S1pr1 is highly expressed in vascular tissues [21,53,54]. Thus, the expression observed may, to some extent, reflect the vascular component of each specific eye tissue. Compared to S1pr1, S1pr 2 expression was very low in the various eye tissues. Yet, we did detect some expression in the iris-ciliary body, optic nerve, eye cup and retina (Figure 2B). S1pr3, on the other hand, was ubiquitously 
expressed in all of the eye tissues examined and displayed very high expression in the optic nerve (Figure 2B).

We further determined the expression levels of sphingosine kinases and S1P receptors in whole eyes of mice during embryonic development (E15 and E18) and adulthood (at 2 and 7 months) by using qRT-PCR. As seen in our previous rat data, Sphk2 was highly expressed throughout early development and adulthood while Sphk1 expression remained relatively low at all stages (Figure 2C). S1pr1 expression was approximately two-fold higher in eyes isolated from adult mice when compared to embryonic eyes (Figure 2D). In contrast, the levels of S1pr 2 mRNA were lower in the developed eyes than the embryonic eyes. In addition, S1pr3 mRNA were relatively constant during embryonic development and in adulthood (Figure 2D). S1pr3 was more highly expressed than S1pr2 at all ages (Figure 2D).

In the developing mouse retina, both Sphk1 and Sphk2 expression appear to increase during early retinal development and peak at adulthood levels by postnatal day 30 (P30) (Figure 2E). Retinal S1pr1 receptor expression gradually increases from P1 to P15 (Figure 2F), which could be related to retinal vascular development in this tissue. The retina is initially avascular when a mouse is born. However, starting at $\mathrm{P} 1$, the vasculature grows radially from the center of the retina towards the periphery until the retina reaches its mature size at around P15 [55,56]. S1pr1 expression in the retina may, therefore, reflect the gradual increase of the vascular volume in the retina. S1pr2 had lower levels of expression through all stages of retinal development while S1pr3 expression was relatively high and constant at all time points (Figure 2F). To monitor stages of retinal development, we evaluated the expression of the markers Elovl4 and Rhodopsin and found that they follow the expected pattern (Supplementary Figure S1).
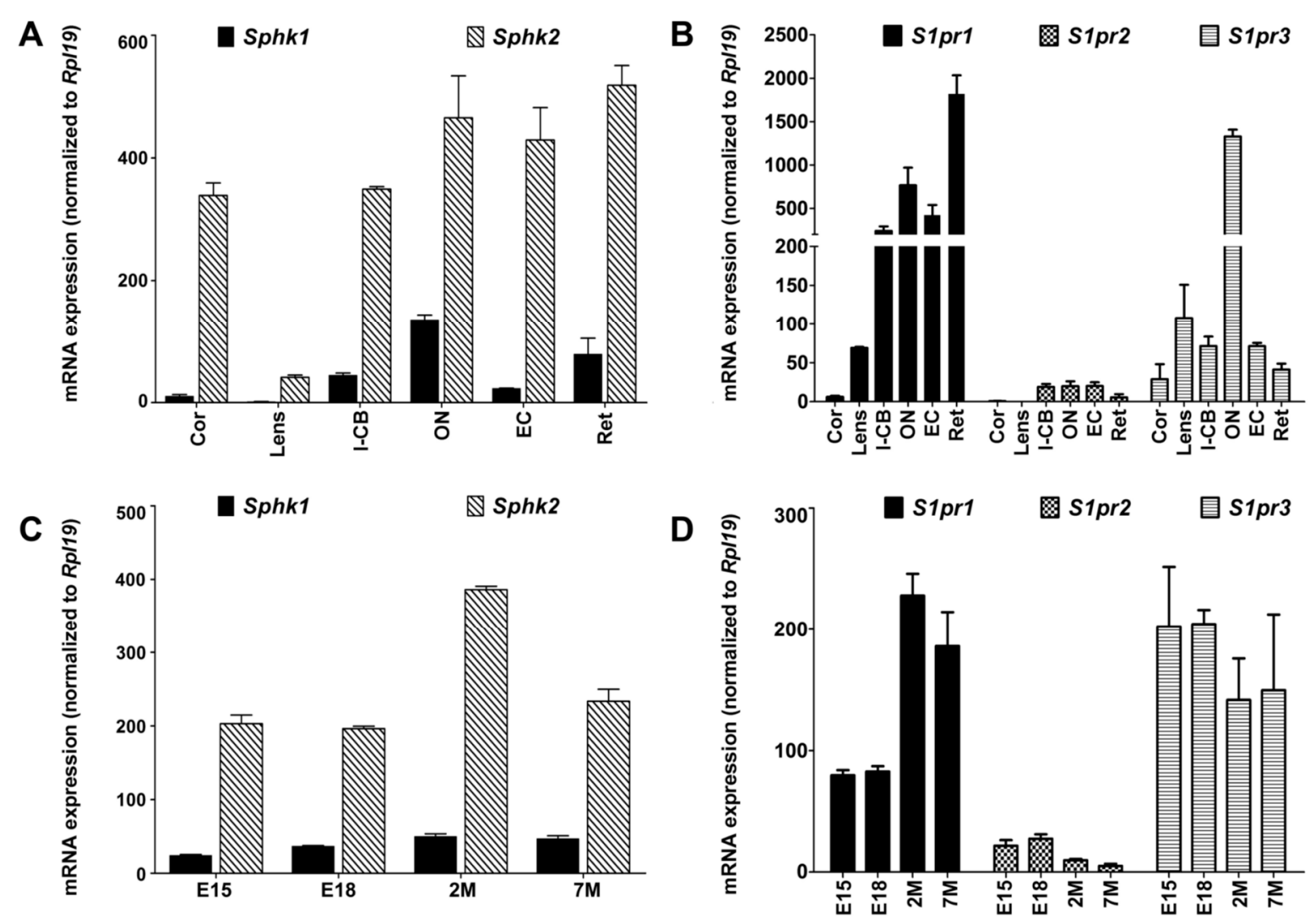

Figure 2. Cont. 

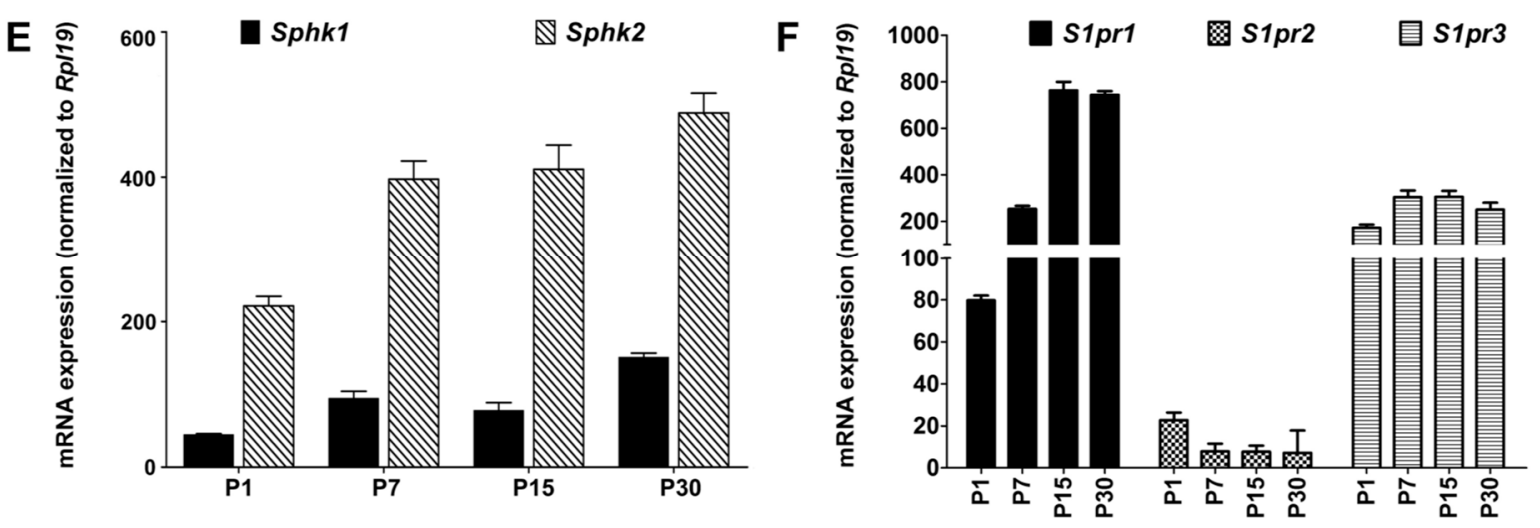

Figure 2. The expression and distribution of sphingosine kinase (Sphk) 1 and 2 and sphingosine 1-phosphate receptor (S1pr) 1, 2 and 3 mRNA in mouse eye tissues. Each bar shows the mean of three independent qRT-PCR experiments $( \pm \mathrm{SE})$ normalized with the expression of the ribosomal protein Rp119. (A) Sphk1 and Sphk2 expression profile in mouse eye tissues. (B) S1pr1-3 expression profile in mouse eye tissues. (C) Sphk1-2 expression profile in embryonic and adult whole mouse eyes. (D) S1pr1-3 expression profile in embryonic and adult whole mouse eyes. (E) Sphk1-2 expression profile in developing mouse retinas from postnatal day 1 (P1) to P30. (F) S1pr1-3 expression profile in developing mouse retinas from P1 to P30. Cor, cornea. I-CB, iris/ciliary body. ON, optic nerve. EC, eye cup. Ret, retina. E15, 15 day embryo. E18, 18 day embryo. 2M, 2 months aged. 7M, 7 months aged. P1, P7, P15 and P30 are postnatal day 1, 7, 15 and 30, respectively.

\subsection{Localization of Major S1P Receptors and Sphingosine Kinases in Rat Eye Tissues and Retina}

\subsubsection{Localization of SPHK1 and SPHK2}

To observe the localization of SPHK1 and SPHK2 in the retina and cornea, we performed immunohistochemistry (IHC) on sections of rat eyes taken through the vertical meridian and the optic nerve head using anti-SPHK1 and anti-SPHK2 antibodies. IHC localization of SPHK1 showed expression throughout the retina with strong staining in the ganglion cell bodies, large puncta in the IPL and extranuclear staining in photoreceptor cell bodies (Figure 3B-arrowheads). SPHK1 also showed expression in the corneal epithelium (Figure 3C-arrowheads). No-primary controls for corneal staining is shown in supplemental figures (Figure S2A). SPHK2 expression was observed throughout the retina notably in the RPE, ONL, INL and GCL (Figure 3E-arrowheads). We also noted some SPHK2 expression in the corneal epithelium (Figure 3F-arrowheads).
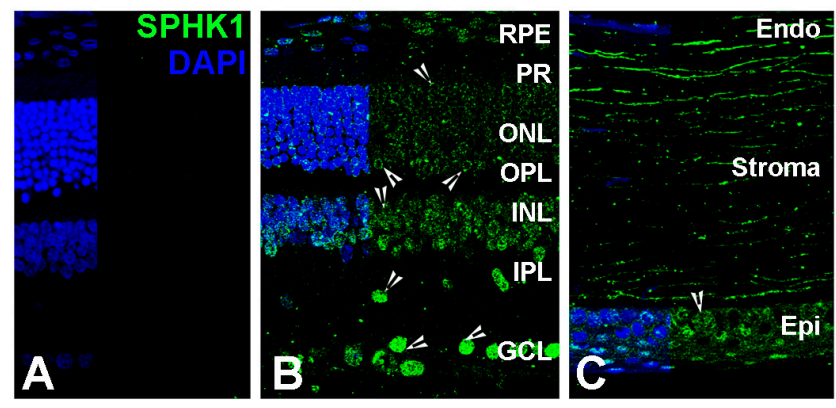

Figure 3. Cont. 


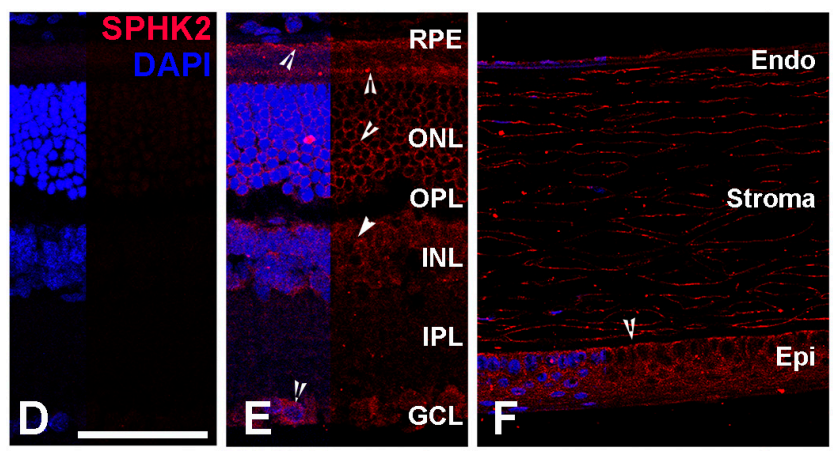

Figure 3. Localization of SPHK1 and SPHK2 in adult (2-7 months old) rat ocular tissues. SPHK1 and SPHK2 localization was detected by anti-SPHK1 (green) and anti-SPHK2 (red) antibodies. (A) Rat retinal section in which the anti-SPHK1 antibodies were replaced with normal rabbit serum. The layers were marked and served as a negative control. (B) Retinal section of SD rat eye and SPHK1 localization in different layers is shown by arrowheads. (C) Corneal section of SD rat eye and SPHK1 localization in different layers is shown by arrowheads. (D) Rat retinal section in which the anti-SPHK2 antibodies were replaced with normal rabbit serum. The layers were marked and served as a negative control. (E) Retinal section of SD rat eye and SPHK2 localization in different layers is shown by arrowheads. (F) Corneal section of SD rat eye and SPHK2 localization in different layers is shown by arrowheads. CB, ciliary body. RPE, retinal pigment epithelium. PR, photoreceptor. ONL, outer nuclear layer. OPL, outer plexiform layer. INL, inner nuclear layer. IPL, inner plexiform layer. GCL, ganglion cell layer. Endo, endothelium. Epi, epithelium. Scale $=50 \mu \mathrm{m}$.

\subsubsection{Localization of S1PR1}

Little is known about the localization of S1PR1 in the neural retina and other eye tissues. We detected prominent labeling on retinal pigment epithelial (RPE) cells and photoreceptor cells with an anti-S1PR1 receptor antibody but not an IgG control (Figure 4A,B, arrowheads). However, we did not detect expression of S1PR1 in other parts of the eye such as the iris, lens (data not shown), or ciliary body (Figure 4C,D). In general, no localization of S1PR1 was noticed in the cornea. Corneal stromal labeling could be non-specific binding of the fluorescent antibody to the collagenous stroma (Figure 4C, arrows), as we did not detect this labeling in no-primary controls (Supplementary Figure S2B).

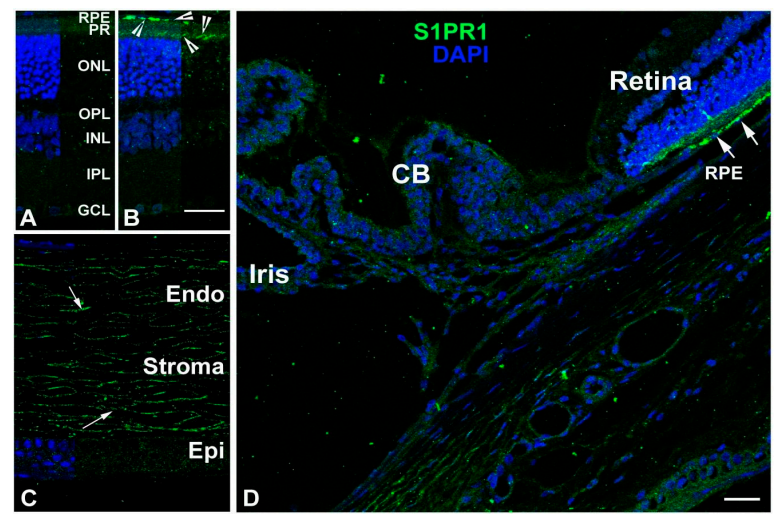

Figure 4. Localization of S1PR1 in adult (2-7 months old) rat ocular tissues. S1PR1 localization (green) was detected with anti-S1PR1 antibodies. (A) Rat retinal section in which the anti-S1PR1 antibodies were replaced with normal rabbit serum. The layers were marked and served as a negative control. (B) Retinal section of SD rat eye and S1PR1 localization in different layers is shown by arrowheads. (C) Corneal section of SD rat eye with S1PR1 labeling. (D) Partial anterior segment of eye containing ciliary epithelial cells, trabecular meshwork and Schlemm's canal. S1PR1 localization is shown by arrowheads. RPE, retinal pigment epithelium. PR, photoreceptor. ONL, outer nuclear layer. OPL, outer plexiform layer. INL, inner nuclear layer. IPL, inner plexiform layer. GCL, ganglion cell layer. Endo, endothelium. Epi, epithelium. CB, ciliary body. Scale $=25 \mu \mathrm{m}$. 


\subsubsection{Localization of S1PR2}

Using IHC, we found that an anti-S1PR2 antibody instead of IgG is labeled the very top layer of cells of the inner nuclear layer (INL) of rat retinal sections (Figure 5A,B,D,E). Since the INL consists primarily of bipolar cells, we sought to determine if the S1PR2 receptor colocalizes with PKC $\alpha$, which is a marker of bipolar cell dendrites. We found that S1PR2 was present on the cell body of bipolar cells but did not overlap with the dendrites (Figure 5D, arrowheads). We also found that anti-S1PR2 antibodies labeled the corneal epithelium but not the corneal endothelium or stroma (Figure 5C). Lastly, punctate labeling of S1PR2 was prominent around the large vacuoles and Schlemm's canal in the outflow pathway (Figure 5F, arrowheads).

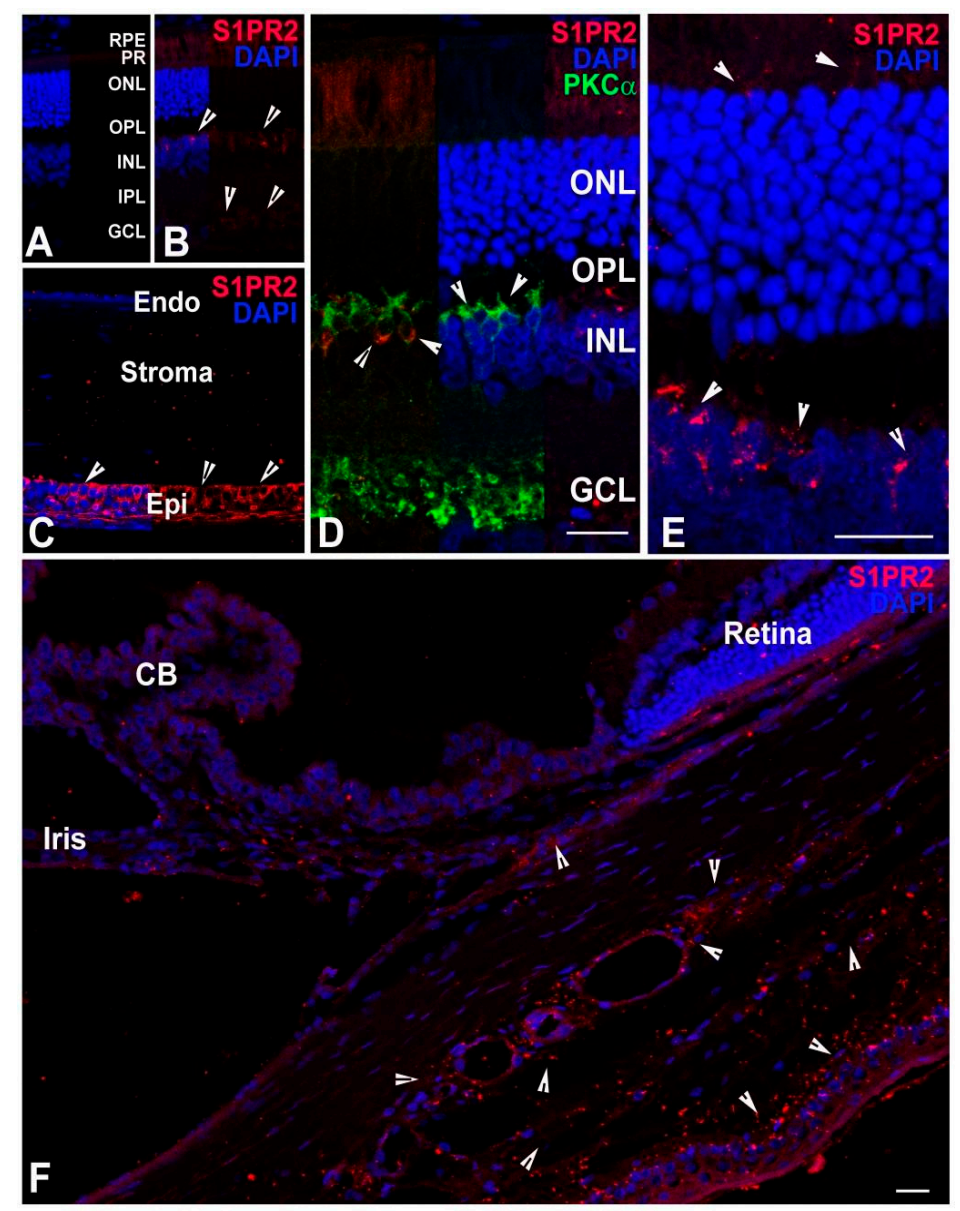

Figure 5. Localization of S1PR2 in adult (2-7 months old) rat ocular tissues. S1PR2 localization (red) was detected by anti-S1PR2 antibodies. (A) Rat retinal section in which the anti-S1PR2 antibodies were replaced with normal goat serum. The layers were marked and served as a negative control. (B) Retinal section of SD rat eye and S1PR2 localization in different layers is shown by arrowheads. (C) Corneal section of SD rat eye and S1PR2 localization in different layers is shown by arrowheads. (D) Magnified view of SD rat retinal section and S1PR2 localization with respect to PKC $\alpha$ in the INL and OPL layer, which is shown by arrowheads. (E) Magnified view of SD rat retinal section with emphasis on inner nuclear layer (INL) localization of S1PR2 shown by arrowheads. (F) Partial anterior segment of SD rat eye containing ciliary epithelial cells, Trabecular meshwork and Schlemm's canal. S1PR2 localization is shown by arrowheads. CB, ciliary body. RPE, retinal pigment epithelium. PR, photoreceptor. ONL, outer nuclear layer. OPL, outer plexiform layer. INL, inner nuclear layer. IPL, inner plexiform layer. GCL, ganglion cell layer. Endo, endothelium. Epi, epithelium. Scale $=25 \mu \mathrm{m}$. 


\subsubsection{Localization of S1PR3}

Using IHC on SD rat retinal sections, we detected expression of S1PR3 in the ganglion cells and photoreceptor cells along with some expression in the photoreceptor inner segment region (inner nuclear layer) (Figure 6A,B, arrowheads). In the other parts of the eye, we observed strong anti-S1PR3 receptor staining of the corneal epithelium and some staining of the corneal endothelium (Figure 6C, arrowheads). Although the S1PR3 receptor was not detected in the corneal stroma (Figure 6C), it was observed in the pigmented epithelial cells of the ciliary body and iris (Figure 6D, arrowheads). Focal clustered labeling was observed around the Schlemm's canal (Figure 6D, arrowheads).
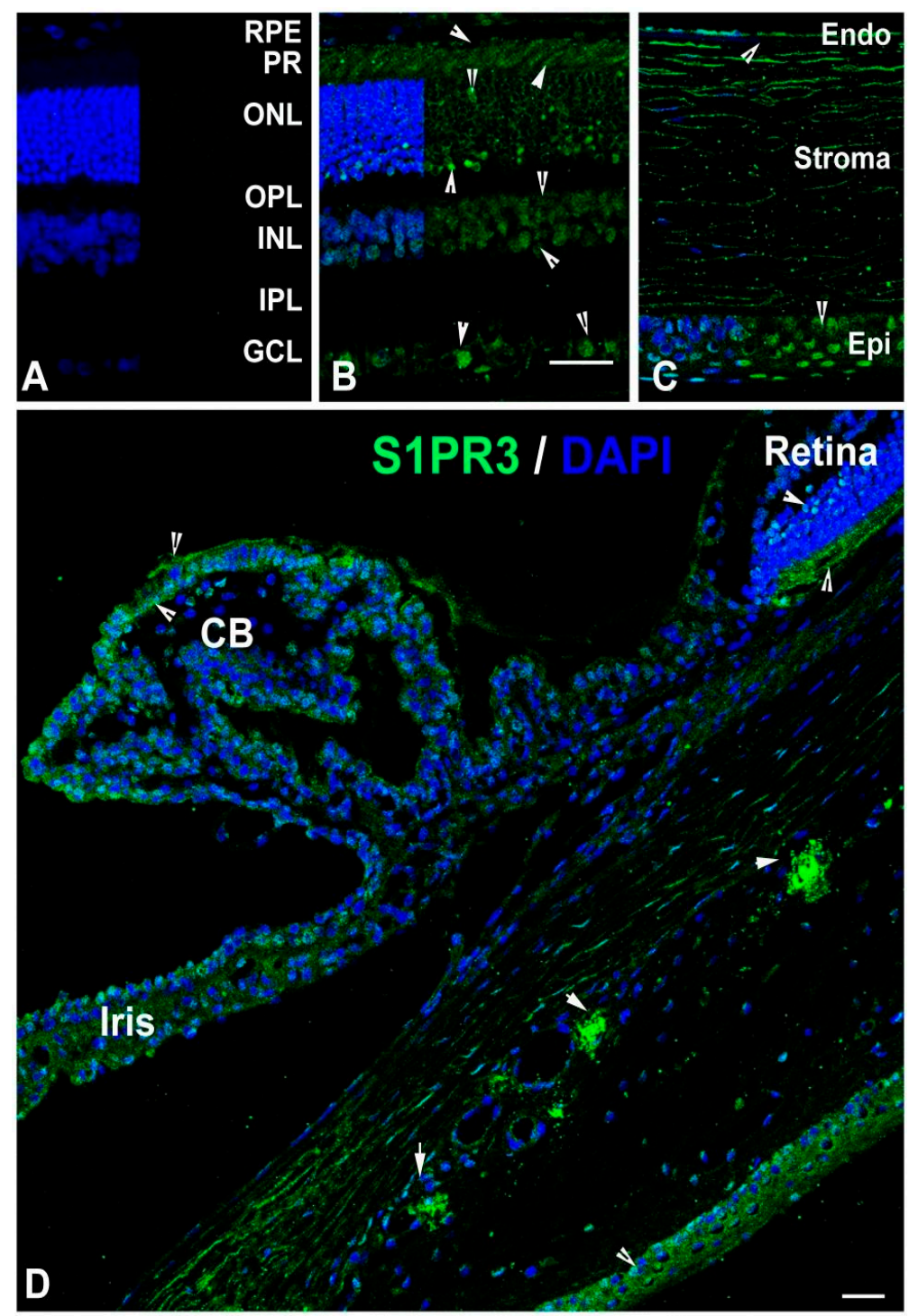

Figure 6. Localization of S1PR3 in adult (2-7 months old) rat ocular tissues. S1PR3 localization (green) was detected by anti-S1PR3 antibodies. (A) The rat retinal section in which the anti-S1PR3 antibodies were replaced with normal rabbit serum. The layers were marked and served as a negative control. (B) The retinal section of SD rat eye and S1PR3 localization in different layers is shown by arrowheads. (C) The corneal section of SD rat eye and S1PR3 localization in different layers is shown by arrowheads. (D) Partial anterior segment of SD rat eye containing ciliary epithelial cells, trabecular meshwork and Schlemm's canal. The S1PR3 localization is shown by arrowheads. CB, ciliary body. $\mathrm{RPE}$, retinal pigment epithelium. PR, photoreceptor. ONL, outer nuclear layer. OPL, outer plexiform layer. INL, inner nuclear layer. IPL, inner plexiform layer. GCL, ganglion cell layer. Endo, endothelium. Epi, epithelium. Scale $=25 \mu \mathrm{m}$. 


\subsection{Expression and Distribution of Sphingosine Kinases and S1P Receptors in Light Stressed Retinas}

In order to examine the expression of Sphk1-2 and the three major S1P receptors under light stress, we used our light-damaged rat retina model in which photoreceptor cell death occurs by apoptosis mainly due to oxidative stress induced by intense light exposure. Apoptosis starts after 8-12 h and by $24 \mathrm{~h}$ almost all of the photoreceptor cells in the central retina enter into apoptosis [57-60]. Using qRT-PCR, we observed a significant and sustained increase in Sphk1 mRNA expression following light damage. Notably, Sphk1 mRNA was elevated by four-fold, seven-fold and six-fold at LD + 0, LD + 3 and LD + 6, respectively, and began trending back toward baseline at $12 \mathrm{~h}(p<0.01$, Figure $7 \mathrm{~A})$. However, only a slight, non-significant elevation in Sphk2 expression was recorded following light damage (Figure 7A). S1pr 2 and S1pr3 mRNA expression increased significantly immediately after light damage (LD+0) by five-fold $(p<0.05)$ and twenty-fold $(p<0.01)$, respectively (Figure 7B). S1pr2 and S1pr3 expression returned to basal levels after $3 \mathrm{~h}$ and $S 1 p r 1$ expression remained constant throughout the experiment (Figure 7B).

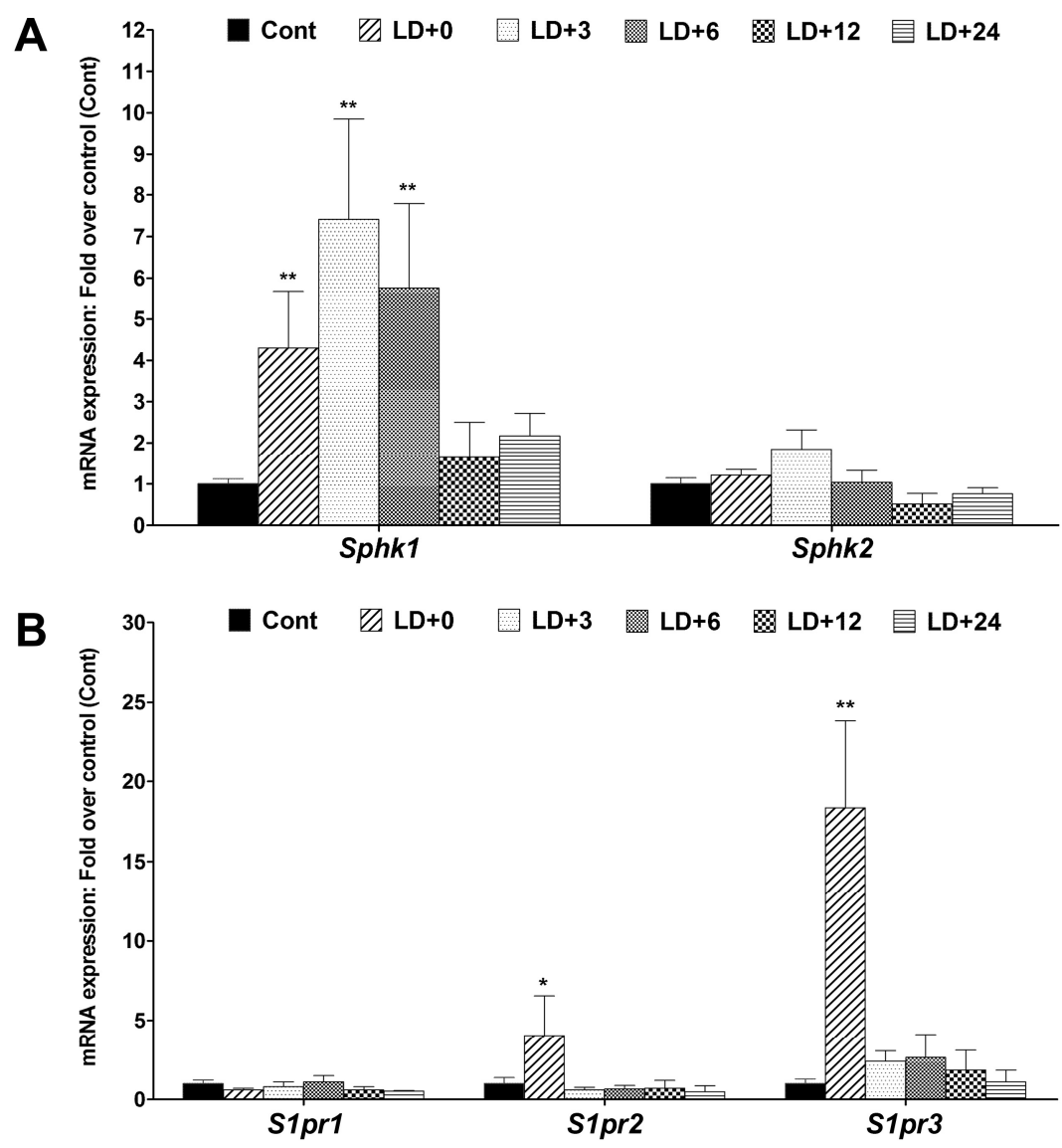

Figure 7. Light stress modulates sphingosine kinase (Sphk) 1 and 2 and sphingosine 1-phosphate receptor (S1pr) 1, 2 and 3 mRNA expression in adult (2-4 months old) rat retinas. Adult SD rats were exposed to damaging light at an intensity of $2700 \mathrm{lux}$ for $6 \mathrm{~h}$ and their retinas were then harvested at different time points after light damage: $0 \mathrm{~h}(\mathrm{LD}+0), 3 \mathrm{~h}(\mathrm{LD}+3), 6 \mathrm{~h}(\mathrm{LD}+6), 12 \mathrm{~h}(\mathrm{LD}+12)$ and $24 \mathrm{~h}$ $(\mathrm{LD}+24)$. Harvested samples were prepared for RNA extraction and subsequent qRT-PCR. (A) mRNA expression of Sphk1 and Sphk2 were presented as fold over control. (B) mRNA expression of S1pr1, S1pr2 and S1pr3 presented as fold over control. The expression data were calculated by $\mathrm{dCt}$ methods and compared to the expression of control housekeeping genes. The data presented are the mean of three independent experiments $( \pm S E)$.

We further examined protein localization in the retina immediately after light damage (LD +0$)$. No labeling of S1PR2 was detected in the photoreceptor nuclei (ONL) in the no-light-damaged retina 
(NLD, Figure 8A). However, at LD + 0, we detected abundant expression of S1PR2 in the photoreceptor cells, which may be undergoing apoptosis (Figure 8B). S1PR2 labeling increased in the ganglion cells after light damage as well (Figure 8B, arrowhead). S1PR3 labeling also increased and intensely co-localized with S1PR2 in photoreceptor cells after light damage (Figure 8D,E).

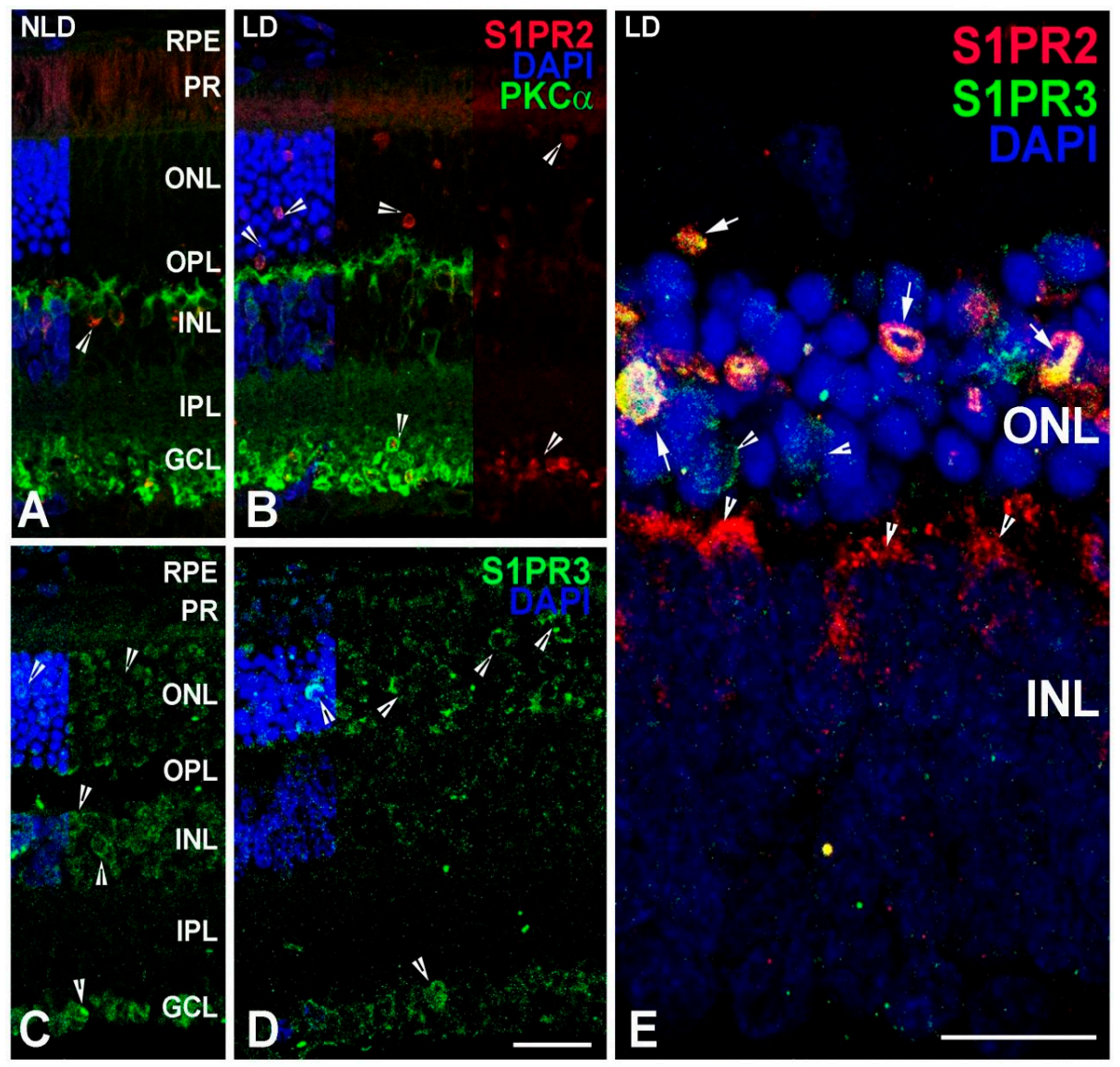

Figure 8. Localization of S1PR2, S1PR3 and PKC $\alpha$ in light damaged (LD) and non-light damaged (NLD) adult (2-4 months old) rat retinal tissues. (A) Retinal section of NLD SD rat eye with S1PR2 localization in different layers shown by arrowheads. (B) Retinal section of LD SD rat eye with S1PR2 localization in different layers shown by arrowheads. (C) Retinal section of NLD SD rat eye with S1PR3 localization in different layers shown by arrowheads. (D) Retinal section of LD SD rat eye with S1PR3 localization in different layers shown by arrowheads. (E) Magnified view of LD SD rat eye showing localization of S1PR2 and S1PR3 in the ONL and INL with arrowheads. RPE, retinal pigment epithelium. PR, photoreceptor. ONL, outer nuclear layer. OPL, outer plexiform layer. INL, inner nuclear layer. IPL, inner plexiform layer. GCL, ganglion cell layer. Scale $=25 \mu \mathrm{m}$.

\section{Discussion}

G-protein-mediated signaling via S1P receptors has recently been shown to be involved in various cellular and biochemical processes including cell migration, inflammation, protection from apoptosis, etc. $[5,11,13,21,43,61]$. S1P receptors have been shown to function in neurogenesis, inflammation, neovascularization and tissue fibrosis, which are all associated with many blinding eye diseases. It is, therefore, of great interest and importance to understand the function of sphingolipid metabolism and signaling in the eye. However, very limited information is available on the expression and function of sphingosine kinases and S1P receptors in the mammalian retina and other ocular tissues. To fill this gap in knowledge, we determined the retinal expression levels of the sphingosine kinases (SPHK1 and SPHK2) and major S1P receptors (S1PR1, S1PR2, S1PR3 and S1PR5) relative to other rat tissues. We then evaluated the expression and localization of these kinases and the three major S1P receptors 
in specific ocular tissues from rats and mice and measured changes in their expression and localization following light-induced eye damage (LD).

S1P receptor expression in mammalian eye tissues has been reported previously and mouse S1pr2 expression in the retina has also been reported in the context of neovascularization. S1PR1-3, 5 also had expression demonstrated in human RPE, conjunctival fibroblasts and corneal fibroblasts $[46,54,62]$. The trend of S1P receptor expression in eye tissue follows the general pattern of other tissues $[63,64]$ such as S1pr1 > S1pr3 > S1pr2. The optic nerve has very high expression of S1pr3 and also the highest relative Sphk1 expression levels (Figure 2A,B), which could be of importance in terms of understanding the roles of S1P signaling in many forms of human optic nerve degeneration diseases and glaucoma.

The S1P receptor expression has been studied in detail across different cardiac tissues and reveals similar patterns for many we observed. In both cardiac myocytes and vascular endothelial cells, S1pr1 has the highest expression, followed by S1pr3, and then followed by S1pr2. In cardiac fibroblasts, S1pr3 has higher expression than S1pr1 and, in aortic muscle smooth cells, S1pr2 dominates S1pr1 and S1pr3 [63]. It should be noted that the expression pattern of S1P receptors changes during development and differentiation, which is shown by Figure 2D,F and leads to different combinations on cells and tissues $[33,53,65,66]$. This diversity in receptor expression and activation of divergent signaling pathways may explain how S1P signals have such pleiotropic responses. We focused here on sphingosine kinase and S1P receptor expression in eye tissues to help elucidate their roles in development, differentiation of ocular tissues, and pathogenesis of various eye diseases.

We observed high expression of S1pr1 mRNA in mouse and rat retinas (Figures 1 and 2). As mentioned earlier, S1pr1 is highly expressed in the vasculature [21,53,54]. Therefore, S1pr1 mRNA expression might reflect the amount of vasculature present in that tissue. qRT-PCR revealed increasing Sphk1, Sphk2 and S1pr1 expression with the age in mouse retinas (Figure 2E,F), which could be due to the development of vasculature and/or the development of the outer segments. Using IHC, we found that the neural cells of the mouse eye express negligible levels of S1PR1. However, prominent expression was detected in the RPE-choroid interface and the photoreceptor outer segment (Figure 4). Future studies using mouse models that do not develop outer segments could prove useful in determining the role that S1PR1 plays in the outer segments.

S1PR2, on the other hand, has expression in some inner retinal neurons, which could be rod bipolar cells since those cells can also be labeled with PKC $\alpha$. This specifically labels the dendrites of rod bipolar cells. However, the PKC $\alpha$ and S1PR2 labels do not overlap, which indicates the presence of S1PR2 on the cell membrane of the bipolar cells but not on the dendrites (Figure 5D). This bipolar localization of S1PR2 suggests that this receptor may participate in some form of neurotransmission of bipolar cells through $\mathrm{Gi}, \mathrm{Gq}$, or G12/13 pathways $[16,20,67]$. S1PR2 was also found to localize to the photoreceptor inner segments, which is specifically very close to the outer nuclear layer (Figure 5E). Photoreceptors are primary cilia and the other related primary ciliary structure are the hair cells of the mammalian cochlea. Knocking out S1PR2 causes hair cell degeneration and deafness in mice [67,68]. It will be very interesting to study photoreceptor development and functioning in the S1pr2 knock-out mice to help understand the role of S1PR2 photoreceptor development and function.

Exogenous S1P has been shown to decrease the outflow facility in the entire eyes of porcine, human and mouse models [69-71]. Using several S1P receptor specific agonists and antagonists, S1PR2 activation by exogenous S1P was found to cause an increase in outflow resistance and higher intraocular pressure [69-71]. This could be a potential target for developing therapeutics for regulating intraocular pressure. For the first time, we detected labeling of S1PR2 in the trabecular meshwork cells and higher on the endothelial cells close to the Schlemm's canal (Figure 5F). We also detected intense, focal localization of S1PR3 in some of the proximal endothelial cells to the Schlemm's canal (Figure 6D). S1P signaling is gaining importance with regards to their role in the human aqueous humor outflow pathway and glaucoma [69-71]. Determination of the presence of these receptors in the outflow pathway may bear significant potential to discover novel pathways and mechanisms for glaucoma development. 
We noticed S1PR3 expression also localized to other retinal cells besides the photoreceptor cells (Figure 6B). In the photoreceptor cells, S1PR3 localizes to the cell body but not to the retinal outer segment (Figure 6D,G). S1pr3 has higher expression in the retina and it increases significantly in retinal light-stress (Figures 1, 2 and 7). However, nothing is known on its role in retinal physiology and diseases. There is a potential for discovering novel pathways and mechanisms related to retinal development and function by studying S1PR3 in the retina.

In the light-stressed retina, we observed Sphk1, S1pr2 and S1pr3 expression increases significantly [39] (Figure 7). Light stress especially affects the photoreceptor cells [57,59,72-76]. An increase in the expression of a gene in this condition suggests its association with photoreceptor cell physiology. We found, in the light-stressed retina, that S1P receptors specifically and intensely localized to the pycnotic photoreceptor nuclei, which are entering into apoptosis (Figure 8E). This could be a cellular mechanism to up-regulate cytoprotective S1P signaling to counter the apoptosis, which might even be a feedback regulation of ceramide induced apoptosis of photoreceptor cells. S1P has previously been proposed as a key regulator in photoreceptor development as a stimulator of proliferation. Inhibiting S1P synthesis was shown to block mitogenic effects of glial-derived neurotrophic factor (GDNF) [77]. We have shown intense light-induced ceramide generation can induce apoptosis in photoreceptor cells [39]. We reported the S1P level also increases with light stress, which intensifies the expression of the photoreceptor specific S1P receptors and suggests a definitive signaling in the stressed photoreceptor cells. This could also be related to the G-protein coupled action of S1P receptors to affect channel functioning in the stressed photoreceptor cells. Our light damage model showing upregulation of SPHK2 and S1P receptors may implicate a signal for the immune response [78].

In conclusion, our results unveiled novel patterns of sphingosine kinase and S1P receptor expression and localization in the mammalian eye and retina. In line with previous literature and as discussed above, our results suggest that S1P receptor signaling is involved in numerous key processes in the eye ranging from light-stress and apoptotic responses to retinal and vascular development. The combination of the background high expression of S1pr1, high S1pr1 and S1pr3 expression in the developing retina and increased expression of S1pr2 and S1pr3 in the retina immediately after light-induced stress suggests that sphingolipid signaling plays a role in both vision and apoptosis. S1PR2's presence in the outflow pathway follows logically from past studies on S1P receptor antagonist drugs and S1PR2 specific agonists and has great implications for understanding and treating conditions that include elevated IOP in glaucoma. S1PR2 is also likely involved in neurotransmission in the eye based on its localization to cell membranes in bipolar cells. S1pr3's presence in the retina and upregulation during light damage pose interesting questions for the receptor's poorly understood functions in the eye. These data allow future research to elaborate on not only mechanisms behind the receptors' function in the respective tissues but also identifies potential markers and therapeutic targets for numerous ocular diseases.

\section{Materials and Methods}

\subsection{Animal Care and Tissues}

All procedures were performed, according to the ARVO Statement for the Use of Animals in Ophthalmic and Vision Research and the University of Oklahoma Health Sciences Center (OUHSC) Guidelines for Animals in Research. All protocols were reviewed and approved by the Institutional Animal Care and Use Committees of the OUHSC and the Dean A. McGee Eye Institute (DMEI) (IACUC approval \#: 15-015-B, approval date: 24 February 2015; IACUC approval \# 13-060-T, approval date 16 June 2015). All the tissues used in this study were from albino Sprague Dawley (SD) rats, C57Bl6J mice and bovine retina. Mouse and rat retinal tissues used in this study for gene expression were harvested after overnight dark adaptation.

To study tissue distribution of S1P receptor expression, we prepared RNA from adult (2-7 months old) rat tissue. For every tissue harvest, the rats were first euthanized by carbon dioxide asphyxiation. 
The harvested forebrain, hindbrain, liver, heart, lungs, skin, testes, ovary, spleen and kidney was then snap frozen in liquid $\mathrm{N}_{2}$. Light-adapted and dark-adapted rat retinas were harvested under room-light and red-light, respectively, snap-frozen, and used for preparing rod outer segments (ROS). The whole eyes were harvested and fixed in Prefer fixative (Anatech Ltd., Battle Creek, MI, USA) for 20 to $40 \mathrm{~min}$ and embedded in paraffin. Additionally, $5 \mu \mathrm{m}$-thick sections were prepared from the fixed rat eyes and used for immunohistochemistry.

To study the distribution of gene expression in eye tissues, six to eight eyeballs were obtained from adult mice (2-3 months old) after euthanization and the distal-most 3-mm optic nerve cut from the scleral surface of the eyeballs (ON), posterior segment (PS), retina, iris-ciliary body (I-CB), lens and corneal tissues were collected after dissection. Eyeballs (6 to 8) from embryonic (E15 and E18) and adult (2 and 7 months) mice were collected to study the expression profile of S1P receptors in the whole eye during embryonic and adult stages. To study retinal expression during development, we collected 8 to 10 retinas from four to five C57Bl6J mice at postnatal days P1, P7, P15 and P30.

\subsection{Light Damage of Albino Rat Retina}

Adult (2-4 months old) SD rats were light damaged by being subjected to 2700 lux of white light for $6 \mathrm{~h}$ in specially fabricated light boxes, which was described in previous publications $[39,59,60]$. The retinas were harvested at various time points following the light exposure ( $0 \mathrm{~h}$ to $24 \mathrm{~h}$ ). Eyes were also harvested at various time points, fixed in Prefer fixative (Anatech Ltd., Battle Creek, MI, USA) for 20 to $40 \mathrm{~min}$, embedded in paraffin, and sectioned for conducting immunohistochemistry.

\subsection{Gene Expression Analysis by Quantitative RT-PCR ( $q$ RT-PCR)}

The RNA was isolated and purified from frozen rat tissues using PureLink ${ }^{\circledR}$ Micro-to Midi Total RNA Purification System from Invitrogen (Carlsbad, CA, USA) and following the manufacturer's protocol. Equal quantities $(1.0 \mu \mathrm{g})$ of total RNA from each tissue were converted to first-strand cDNA using SuperScript III First-Strand Synthesis SuperMix (Invitrogen, Carlsbad, CA, USA) for RT-PCR. First-strand cDNA was used for qRT-PCR. Primers for qRT-PCR were intron-spanning (Supplemental Table S1). Quantitative PCR and melt-curve analyses were performed using iQ SYBR Green Supermix (Bio-Rad, Hercules, CA, USA) and an iCycler machine. Relative quantities of expression of the genes of interest in different samples were calculated by the comparative $\mathrm{Ct}$ (threshold cycle) value method $[39,79,80]$.

\subsection{Immunohistochemistry}

Immunolabeling on paraffin sections was performed as described previously $[39,51,52,80]$. The sections were deparaffinized, rehydrated in PBS (phosphate-buffered saline), and nonspecific labeling was blocked using 10\% normal horse serum in PBS for $2 \mathrm{~h}$. Excess blocker was removed and the primary antibody was applied overnight at $4{ }^{\circ} \mathrm{C}$. IHC antibodies were used as follows: SphK1 rabbit polyclonal [1:100-1:200] (Santa Cruz Biotechnology, Santa Cruz, CA, USA), Sphk2 goat polyclonal [1:100-1:200] (Santa Cruz Biotechnology, Santa Cruz, CA), S1PR1 rabbit polyclonal [1:200] (Cayman, Ann Arbor, MI, USA), S1PR2 goat polyclonal [1:100] (Santa Cruz Biotechnology, Santa Cruz, CA, USA), S1PR3 rabbit polyclonal [1:200] (Santa Cruz Biotechnology, Santa Cruz, CA, USA), PKC $\alpha$ rabbit polyclonal [1:200] (Cell Signaling, Danvers, MA, USA), and Rhodopsin mouse monoclonal [1:200] (Abcam, Cambridge, MA, USA). Sections were rinsed and incubated with appropriate secondary antibodies conjugated to fluorescence dye (Alexa flour, Invitrogen, Carlsbad, CA, USA) @ 1:1000 dilution for $1 \mathrm{~h}$ at room temperature to visualize labeling. Sections were rinsed and cover-slipped with ProLong Gold antifade reagent with DAPI (Invitrogen, Carlsbad, CA, USA). Confocal microscopy was performed using an Olympus FluoView FV500 confocal microscopy system (Olympus Microsystems, Center Valley, PA, USA). To ensure quantitative image quality, laser power, pinhole settings, photomultiplier tube settings, and intensity thresholds were kept constant for the used antibody. 


\subsection{Statistical Analyses}

Statistical analyses were performed using GraphPad Prism 5.0 software (GraphPad Software, Inc.; La Jolla, CA, USA). The quantitative data are expressed as mean $\pm \mathrm{SE}$ for each group. One-way or two-way ANOVA and Student's and paired t-tests were performed to assess differences between means.

Supplementary Materials: Supplementary materials can be found at http:/ /www.mdpi.com/1422-0067/19/12/ $3885 /$ s1.

Author Contributions: Conceptualization, N.M. Data curation, H.P., H.Q., N.P. and J.M. Formal analysis, H.P. and N.M. Funding acquisition, N.M. Investigation, N.M. Methodology, H.P., H.Q., N.P. and J.M. Project administration, N.M. Resources, B.H. Supervision, N.M. Validation, N.M. Visualization, H.Q. and N.M. Writing-original draft, H.P. and N.M. Writing-review \& editing, R.G. and N.M.

Funding: This work was supported by the grants from the National Eye Institute, the National Institute of Health (R01 EY-022071, P30 EY-021725), and the National Center for Research Resources, the National Institute of Health (RR-17703), the Foundation Fighting Blindness Inc., USA, and Research to Prevent Blindness, Inc., USA.

Acknowledgments: Robert E. Anderson, Richard S. Brush, Mark Dittmar, Louisa J. Williams, Carolina Abrahan (Fulbright scholar), and Linda S. Boone (from the Department of Ophthalmology, University of Oklahoma Health Sciences Center, Oklahoma City, OK, USA) are gratefully acknowledged by the authors for providing research reagents and technical support.

Conflicts of Interest: The authors declare no conflict of interest. The funders had no role in the design of the study, in the collection, analyses, or interpretation of data, in the writing of the manuscript, or in the decision to publish the results.

\section{Abbreviations}

$\begin{array}{ll}\text { S1P } & \text { Sphingosine 1-Phosphate } \\ \text { S1PR } & \text { Sphingosine 1-Phosphate Receptor } \\ \text { SPHK } & \text { Sphingosine Kinase } \\ \text { Cer } & \text { Ceramide } \\ \text { qRT-PCR } & \text { Quantitative Reverse Transcriptase Polymerase Chain Reaction } \\ \text { RPE } & \text { Retinal Pigment Epithelium } \\ \text { IHC } & \text { Immunohistochemistry } \\ \text { PR } & \text { Photoreceptor } \\ \text { ONL } & \text { Outer Nuclear Layer } \\ \text { OPL } & \text { Outer Plexiform Layer } \\ \text { INL } & \text { Inner Nuclear Layer } \\ \text { IPL } & \text { Inner Plexiform Layer } \\ \text { GCL } & \text { Ganglion Cell Layer } \\ \text { Endo } & \text { Endothelium } \\ \text { Epi } & \text { Epithelium } \\ \text { CB } & \text { Ciliary Body }\end{array}$

\section{References}

1. Futerman, A.H.; Hannun, Y.A. The complex life of simple sphingolipids. EMBO Rep. 2004, 5, 777-782. [CrossRef] [PubMed]

2. Lahiri, S.; Futerman, A.H. The metabolism and function of sphingolipids and glycosphingolipids. Cell. Mol. Life Sci. 2007, 64, 2270-2284. [CrossRef] [PubMed]

3. Merrill, A.H., Jr.; Schmelz, E.M.; Dillehay, D.L.; Spiegel, S.; Shayman, J.A.; Schroeder, J.J.; Riley, R.T.; Voss, K.A.; Wang, E. Sphingolipids-The enigmatic lipid class: Biochemistry, physiology, and pathophysiology. Toxicol. Appl. Pharmacol. 1997, 142, 208-225. [CrossRef] [PubMed]

4. Bielawski, J.; Szulc, Z.M.; Hannun, Y.A.; Bielawska, A. Simultaneous quantitative analysis of bioactive sphingolipids by high-performance liquid chromatography-tandem mass spectrometry. Methods 2006, 39, 82-91. [CrossRef] [PubMed] 
5. Hannun, Y.A.; Obeid, L.M. Principles of bioactive lipid signalling: Lessons from sphingolipids. Nat. Rev. 2008, 9, 139-150. [CrossRef] [PubMed]

6. Zeidan, Y.H.; Hannun, Y.A. Translational aspects of sphingolipid metabolism. Trends Mol. Med. 2007, 13, 327-336. [CrossRef] [PubMed]

7. Chalfant, C.E.; Spiegel, S. Sphingosine 1-phosphate and ceramide 1-phosphate: Expanding roles in cell signaling. J. Cell Sci. 2005, 118, 4605-4612. [CrossRef]

8. Chen, H.; Chan, A.Y.; Stone, D.U.; Mandal, N.A. Beyond the cherry-red spot: Ocular manifestations of sphingolipid-mediated neurodegenerative and inflammatory disorders. Surv. Ophthalmol. 2014, 59, 64-76. [CrossRef]

9. Hoeferlin, L.A.; Wijesinghe, D.S.; Chalfant, C.E. The role of ceramide-1-phosphate in biological functions. Handb. Exp. Pharmacol. 2013, 153-166. [CrossRef]

10. Lamour, N.F.; Chalfant, C.E. Ceramide-1-phosphate: The "missing" link in eicosanoid biosynthesis and inflammation. Mol. Interv. 2005, 5, 358-367. [CrossRef]

11. Maceyka, M.; Spiegel, S. Sphingolipid metabolites in inflammatory disease. Nature 2014, 510, 58-67. [CrossRef] [PubMed]

12. Morales, A.; Lee, H.; Goni, F.M.; Kolesnick, R.; Fernandez-Checa, J.C. Sphingolipids and cell death. Apoptosis 2007, 12, 923-939. [CrossRef] [PubMed]

13. Nixon, G.F. Sphingolipids in inflammation: Pathological implications and potential therapeutic targets. Br. J. Pharmacol. 2009, 158, 982-993. [CrossRef] [PubMed]

14. Pettus, B.J.; Chalfant, C.E.; Hannun, Y.A. Sphingolipids in inflammation: Roles and implications. Curr. Mol. Med. 2004, 4, 405-418. [CrossRef] [PubMed]

15. Schulze, H.; Sandhoff, K. Sphingolipids and lysosomal pathologies. Biochim. Biophys. Acta 2014, 1841, 799-810. [CrossRef] [PubMed]

16. Mizugishi, K.; Yamashita, T.; Olivera, A.; Miller, G.F.; Spiegel, S.; Proia, R.L. Essential role for sphingosine kinases in neural and vascular development. Mol. Cell. Biol. 2005, 25, 11113-11121. [CrossRef] [PubMed]

17. Eresch, J.; Stumpf, M.; Koch, A.; Vutukuri, R.; Ferreiros, N.; Schreiber, Y.; Schroder, K.; Devraj, K.; Popp, R.; Huwiler, A.; et al. Sphingosine Kinase 2 Modulates Retinal Neovascularization in the Mouse Model of Oxygen-Induced Retinopathy. Invest. Ophthalmol. Vis. Sci. 2018, 59, 653-661. [CrossRef] [PubMed]

18. Abrahan, C.E.; Miranda, G.E.; Agnolazza, D.L.; Politi, L.E.; Rotstein, N.P. Synthesis of sphingosine is essential for oxidative stress-induced apoptosis of photoreceptors. Invest. Ophthalmol. Vis. Sci. 2010, 51, 1171-1180. [CrossRef]

19. Chu, A.; Robertson, G.; Brooks, D.; Mungall, A.J.; Birol, I.; Coope, R.; Ma, Y.; Jones, S.; Marra, M.A. Large-scale profiling of microRNAs for The Cancer Genome Atlas. Nucleic Acids Res. 2016, 44, e3. [CrossRef]

20. Kono, M.; Mi, Y.; Liu, Y.; Sasaki, T.; Allende, M.L.; Wu, Y.P.; Yamashita, T.; Proia, R.L. The sphingosine-1-phosphate receptors S1P1, S1P2, and S1P3 function coordinately during embryonic angiogenesis. J. Biol. Chem. 2004, 279, 29367-29373. [CrossRef]

21. Liu, Y.; Wada, R.; Yamashita, T.; Mi, Y.; Deng, C.X.; Hobson, J.P.; Rosenfeldt, H.M.; Nava, V.E.; Chae, S.S.; Lee, M.J.; et al. Edg-1, the G protein-coupled receptor for sphingosine-1-phosphate, is essential for vascular maturation. J. Clin. Investi. 2000, 106, 951-961. [CrossRef] [PubMed]

22. MacLennan, A.J.; Browe, C.S.; Gaskin, A.A.; Lado, D.C.; Shaw, G. Cloning and characterization of a putative G-protein coupled receptor potentially involved in development. Mol. Cell. Neurosci. 1994, 5, 201-209. [CrossRef] [PubMed]

23. McGiffert, C.; Contos, J.J.; Friedman, B.; Chun, J. Embryonic brain expression analysis of lysophospholipid receptor genes suggests roles for $\mathrm{s} 1 \mathrm{p}(1)$ in neurogenesis and $\mathrm{s} 1 \mathrm{p}(1-3)$ in angiogenesis. FEBS Lett. 2002, 531, 103-108. [CrossRef]

24. Ishii, I.; Friedman, B.; Ye, X.; Kawamura, S.; McGiffert, C.; Contos, J.J.; Kingsbury, M.A.; Zhang, G.; Brown, J.H.; Chun, J. Selective loss of sphingosine 1-phosphate signaling with no obvious phenotypic abnormality in mice lacking its G protein-coupled receptor, LP(B3)/EDG-3. J. Biol. Chem. 2001, 276, 33697-33704. [CrossRef]

25. Allende, M.L.; Sasaki, T.; Kawai, H.; Olivera, A.; Mi, Y.; van Echten-Deckert, G.; Hajdu, R.; Rosenbach, M.; Keohane, C.A.; Mandala, S.; et al. Mice deficient in sphingosine kinase 1 are rendered lymphopenic by FTY720. J. Biol. Chem. 2004, 279, 52487-52492. [CrossRef] [PubMed] 
26. Matloubian, M.; Lo, C.G.; Cinamon, G.; Lesneski, M.J.; Xu, Y.; Brinkmann, V.; Allende, M.L.; Proia, R.L.; Cyster, J.G. Lymphocyte egress from thymus and peripheral lymphoid organs is dependent on S1P receptor 1. Nature 2004, 427, 355-360. [CrossRef] [PubMed]

27. Mendelson, K.; Zygmunt, T.; Torres-Vazquez, J.; Evans, T.; Hla, T. Sphingosine 1-phosphate receptor signaling regulates proper embryonic vascular patterning. J. Biol. Chem. 2013, 288, 2143-2156. [CrossRef] [PubMed]

28. Mousseau, Y.; Mollard, S.; Richard, L.; Nizou, A.; Faucher-Durand, K.; Cook-Moreau, J.; Qiu, H.; Baaj, Y.; Funalot, B.; Fourcade, L.; et al. Fingolimod inhibits PDGF-B-induced migration of vascular smooth muscle cell by down-regulating the S1PR1/S1PR3 pathway. Biochimie 2012, 94, 2523-2531. [CrossRef]

29. Gandy, K.A.; Canals, D.; Adada, M.; Wada, M.; Roddy, P.; Snider, A.J.; Hannun, Y.A.; Obeid, L.M. Sphingosine 1-phosphate induces filopodia formation through S1PR2 activation of ERM proteins. Biochem. J. 2013, 449, 661-672. [CrossRef]

30. Agarwal, A.; Ingham, S.A.; Harkins, K.A.; Do, D.V.; Nguyen, Q.D. The role of pharmacogenetics and advances in gene therapy in the treatment of diabetic retinopathy. Pharmacogenomics 2016, 17, 309-320. [CrossRef]

31. Abou, R.; Leung, M.; Khidir, M.J.H.; Wolterbeek, R.; Schalij, M.J.; Ajmone Marsan, N.; Bax, J.J.; Delgado, V. Influence of Aging on Level and Layer-Specific Left Ventricular Longitudinal Strain in Subjects Without Structural Heart Disease. Am. J. Cardiol. 2017, 120, 2065-2072. [CrossRef]

32. Donati, F.; Acciarini, R.; De Benedittis, I.; de la Torre, X.; Pirri, D.; Prete, M.; Stampella, A.; Vernucci, E.; Botre, F. Detecting Autologous Blood Transfusion in Doping Control: Biomarkers of Blood Aging and Storage Measured by Flow Cytofluorimetry. Curr. Pharm. Biotechnol. 2018, 19, 124-135. [CrossRef] [PubMed]

33. Graler, M.H.; Bernhardt, G.; Lipp, M. EDG6, a novel G-protein-coupled receptor related to receptors for bioactive lysophospholipids, is specifically expressed in lymphoid tissue. Genomics 1998, 53, 164-169. [CrossRef]

34. Im, D.S.; Heise, C.E.; Ancellin, N.; O’Dowd, B.F.; Shei, G.J.; Heavens, R.P.; Rigby, M.R.; Hla, T.; Mandala, S.; McAllister, G.; et al. Characterization of a novel sphingosine 1-phosphate receptor, Edg-8. J. Biol. Chem. 2000, 275, 14281-14286. [CrossRef] [PubMed]

35. Blein-Nicolas, M.; Albertin, W.; da Silva, T.; Valot, B.; Balliau, T.; Masneuf-Pomarede, I.; Bely, M.; Marullo, P.; Sicard, D.; Dillmann, C.; et al. A Systems Approach to Elucidate Heterosis of Protein Abundances in Yeast. Mol. Cell. Proteom. 2015, 14, 2056-2071. [CrossRef] [PubMed]

36. Kehrl, J.H.; Hwang, I.Y.; Park, C. Chemoattract receptor signaling and its role in lymphocyte motility and trafficking. Curr. Top. Microbiol. Immunol. 2009, 334, 107-127. [PubMed]

37. O'Sullivan, C.; Schubart, A.; Mir, A.K.; Dev, K.K. The dual S1PR1/S1PR5 drug BAF312 (Siponimod) attenuates demyelination in organotypic slice cultures. J. Neuroinflamm. 2016, 13, 31. [CrossRef] [PubMed]

38. Bravo, D.; Pardo-Diaz, S.; Benavides-Erazo, J.; Rengifo-Estrada, G.; Braissant, O.; Leon-Moreno, C. Cadmium and cadmium-tolerant soil bacteria in cacao crops from northeastern Colombia. J. Appl. Microbiol. 2018, 124, 1175-1194. [CrossRef]

39. Chen, H.; Tran, J.T.; Eckerd, A.; Huynh, T.P.; Elliott, M.H.; Brush, R.S.; Mandal, N.A. Inhibition of de novo ceramide biosynthesis by FTY720 protects rat retina from light-induced degeneration. J. Lipid Res. 2013, 54, 1616-1629. [CrossRef]

40. Cuvillier, O.; Pirianov, G.; Kleuser, B.; Vanek, P.G.; Coso, O.A.; Gutkind, S.; Spiegel, S. Suppression of ceramide-mediated programmed cell death by sphingosine-1-phosphate. Nature 1996, 381, 800-803. [CrossRef]

41. Jayadev, S.; Liu, B.; Bielawska, A.E.; Lee, J.Y.; Nazaire, F.; Pushkareva, M.; Obeid, L.M.; Hannun, Y.A. Role for ceramide in cell cycle arrest. J. Biol. Chem. 1995, 270, 2047-2052. [CrossRef] [PubMed]

42. Obeid, L.M.; Linardic, C.M.; Karolak, L.A.; Hannun, Y.A. Programmed cell death induced by ceramide. Science 1993, 259, 1769-1771. [CrossRef] [PubMed]

43. Watterson, K.; Sankala, H.; Milstien, S.; Spiegel, S. Pleiotropic actions of sphingosine-1-phosphate. Prog. Lipid Res. 2003, 42, 344-357. [CrossRef]

44. Chen, D.; Meng, L.; Pei, F.; Zheng, Y.; Leng, J. A review of DNA methylation in depression. J. Clin. Neurosci. 2017, 43, 39-46. [CrossRef] [PubMed]

45. Stiles, M.; Qi, H.; Sun, E.; Tan, J.; Porter, H.; Allegood, J.; Chalfant, C.E.; Yasumura, D.; Matthes, M.T.; LaVail, M.M.; et al. Sphingolipid profile alters in retinal dystrophic P23H-1 rats and systemic FTY720 can delay retinal degeneration. J. Lipid Res. 2016, 57, 818-831. [CrossRef] 
46. Caballero, S.; Swaney, J.; Moreno, K.; Afzal, A.; Kielczewski, J.; Stoller, G.; Cavalli, A.; Garland, W.; Hansen, G.; Sabbadini, R.; et al. Anti-sphingosine-1-phosphate monoclonal antibodies inhibit angiogenesis and sub-retinal fibrosis in a murine model of laser-induced choroidal neovascularization. Exp. Eye Res. 2009, 88, 367-377. [CrossRef]

47. Commodaro, A.G.; Bombardieri, C.R.; Peron, J.P.; Saito, K.C.; Guedes, P.M.; Hamassaki, D.E.; Belfort, R.N.; Rizzo, L.V.; Belfort, R., Jr.; de Camargo, M.M. p38\{alpha\} MAP kinase controls IL-17 synthesis in vogt-koyanagi-harada syndrome and experimental autoimmune uveitis. Investig. Ophthalmol. Vis. Sci. 2010, 51, 3567-3574. [CrossRef]

48. Strochlic, L.; Dwivedy, A.; van Horck, F.P.; Falk, J.; Holt, C.E. A role for S1P signalling in axon guidance in the Xenopus visual system. Development 2008, 135, 333-342. [CrossRef]

49. Abdelmagid, S.M.; Barbe, M.F.; Safadi, F.F. Role of inflammation in the aging bones. Life Sci. 2015, 123, 25-34. [CrossRef]

50. Mandal, M.N.; Ayyagari, R. Complement factor H: Spatial and temporal expression and localization in the eye. Investig. Ophthalmol. Vis. Sci. 2006, 47, 4091-4097. [CrossRef]

51. Mandal, M.N.; Vasireddy, V.; Jablonski, M.M.; Wang, X.; Heckenlively, J.R.; Hughes, B.A.; Reddy, G.B.; Ayyagari, R. Spatial and temporal expression of MFRP and its interaction with CTRP5. Investig. Ophthalmol. Vis. Sci. 2006, 47, 5514-5521. [CrossRef] [PubMed]

52. Mandal, M.N.; Vasireddy, V.; Reddy, G.B.; Wang, X.; Moroi, S.E.; Pattnaik, B.R.; Hughes, B.A.; Heckenlively, J.R.; Hitchcock, P.F.; Jablonski, M.M.; et al. CTRP5 is a membrane-associated and secretory protein in the RPE and ciliary body and the S163R mutation of CTRP5 impairs its secretion. Investig. Ophthalmol. Vis. Sci. 2006, 47, 5505-5513. [CrossRef] [PubMed]

53. Liu, C.H.; Hla, T. The mouse gene for the inducible G-protein-coupled receptor edg-1. Genomics 1997, 43, 15-24. [CrossRef] [PubMed]

54. Skoura, A.; Sanchez, T.; Claffey, K.; Mandala, S.M.; Proia, R.L.; Hla, T. Essential role of sphingosine 1-phosphate receptor 2 in pathological angiogenesis of the mouse retina. J. Clin. Investig. 2007, 117, 2506-2516. [CrossRef] [PubMed]

55. Dorrell, M.I.; Friedlander, M. Mechanisms of endothelial cell guidance and vascular patterning in the developing mouse retina. Prog. Retin. Eye Res. 2006, 25, 277-295. [CrossRef] [PubMed]

56. Stahl, A.; Connor, K.M.; Sapieha, P.; Chen, J.; Dennison, R.J.; Krah, N.M.; Seaward, M.R.; Willett, K.L.; Aderman, C.M.; Guerin, K.I.; et al. The mouse retina as an angiogenesis model. Investig. Ophthalmol. Vis. Sci. 2010, 51, 2813-2826. [CrossRef] [PubMed]

57. Gordon, W.C.; Casey, D.M.; Lukiw, W.J.; Bazan, N.G. DNA damage and repair in light-induced photoreceptor degeneration. Investig. Ophthalmol. Vis. Sci. 2002, 43, 3511-3521.

58. Hafezi, F.; Marti, A.; Munz, K.; Reme, C.E. Light-induced apoptosis: Differential timing in the retina and pigment epithelium. Exp. Eye Res. 1997, 64, 963-970. [CrossRef] [PubMed]

59. Mandal, M.N.; Moiseyev, G.P.; Elliott, M.H.; Kasus-Jacobi, A.; Li, X.; Chen, H.; Zheng, L.; Nikolaeva, O.; Floyd, R.A.; Ma, J.X.; et al. Alpha-phenyl-N-tert-butylnitrone (PBN) prevents light-induced degeneration of the retina by inhibiting RPE65 protein isomerohydrolase activity. J. Biol. Chem. 2011, 286, 32491-32501. [CrossRef] [PubMed]

60. Mandal, M.N.; Patlolla, J.M.; Zheng, L.; Agbaga, M.P.; Tran, J.T.; Wicker, L.; Kasus-Jacobi, A.; Elliott, M.H.; Rao, C.V.; Anderson, R.E. Curcumin protects retinal cells from light-and oxidant stress-induced cell death. Free Radic. Biol. Med. 2009, 46, 672-679. [CrossRef]

61. Hla, T. Signaling and biological actions of sphingosine 1-phosphate. Pharmacol. Res. 2003, 47, $401-407$. [CrossRef]

62. Swaney, J.S.; Moreno, K.M.; Gentile, A.M.; Sabbadini, R.A.; Stoller, G.L. Sphingosine-1-phosphate (S1P) is a novel fibrotic mediator in the eye. Exp. Eye Res. 2008, 87, 367-375. [CrossRef] [PubMed]

63. Means, C.K.; Brown, J.H. Sphingosine-1-phosphate receptor signalling in the heart. Cardiovasc. Res. 2009, 82, 193-200. [CrossRef] [PubMed]

64. Kays, J.S.; Li, C.; Nicol, G.D. Expression of sphingosine 1-phosphate receptors in the rat dorsal root ganglia and defined single isolated sensory neurons. Physiol. Genom. 2012, 44, 889-901. [CrossRef] [PubMed]

65. Hecht, J.H.; Weiner, J.A.; Post, S.R.; Chun, J. Ventricular zone gene-1 (vzg-1) encodes a lysophosphatidic acid receptor expressed in neurogenic regions of the developing cerebral cortex. J. Cell Biol. 1996, 135, 1071-1083. [CrossRef] [PubMed] 
66. Zhang, G.; Contos, J.J.; Weiner, J.A.; Fukushima, N.; Chun, J. Comparative analysis of three murine G-protein coupled receptors activated by sphingosine-1-phosphate. Gene 1999, 227, 89-99. [CrossRef]

67. Kono, M.; Belyantseva, I.A.; Skoura, A.; Frolenkov, G.I.; Starost, M.F.; Dreier, J.L.; Lidington, D.; Bolz, S.S.; Friedman, T.B.; Hla, T.; et al. Deafness and stria vascularis defects in S1P2 receptor-null mice. J. Biol. Chem. 2007, 282, 10690-10696. [CrossRef] [PubMed]

68. Herr, D.R.; Grillet, N.; Schwander, M.; Rivera, R.; Muller, U.; Chun, J. Sphingosine 1-phosphate (S1P) signaling is required for maintenance of hair cells mainly via activation of S1P2. J. Neurosci. 2007, 27, 1474-1478. [CrossRef] [PubMed]

69. Stamer, W.D.; Read, A.T.; Sumida, G.M.; Ethier, C.R. Sphingosine-1-phosphate effects on the inner wall of Schlemm's canal and outflow facility in perfused human eyes. Exp. Eye Res. 2009, 89, 980-988. [CrossRef]

70. Boussommier-Calleja, A.; Bertrand, J.; Woodward, D.F.; Ethier, C.R.; Stamer, W.D.; Overby, D.R. Pharmacologic manipulation of conventional outflow facility in ex vivo mouse eyes. Investig. Ophthalmol. Vis. Sci. 2012, 53, 5838-5845. [CrossRef] [PubMed]

71. Sumida, G.M.; Stamer, W.D. S1P(2) receptor regulation of sphingosine-1-phosphate effects on conventional outflow physiology. Am. J. Physiol. Cell Physiol. 2011, 300, C1164-C1171. [CrossRef] [PubMed]

72. Hafezi, F.; Steinbach, J.P.; Marti, A.; Munz, K.; Wang, Z.Q.; Wagner, E.F.; Aguzzi, A.; Reme, C.E. The absence of c-fos prevents light-induced apoptotic cell death of photoreceptors in retinal degeneration in vivo. Nat. Med. 1997, 3, 346-349. [CrossRef] [PubMed]

73. Hao, W.; Wenzel, A.; Obin, M.S.; Chen, C.K.; Brill, E.; Krasnoperova, N.V.; Eversole-Cire, P.; Kleyner, Y.; Taylor, A.; Simon, M.I.; et al. Evidence for two apoptotic pathways in light-induced retinal degeneration. Nat. Genet. 2002, 32, 254-260. [CrossRef]

74. Noell, W.K.; Walker, V.S.; Kang, B.S.; Berman, S. Retinal damage by light in rats. InvestIG. Ophthalmol. 1966, $5,450-473$.

75. Organisciak, D.T.; Vaughan, D.K. Retinal light damage: Mechanisms and protection. Prog. Retin. Eye Res. 2010, 29, 113-134. [CrossRef]

76. Wenzel, A.; Reme, C.E.; Williams, T.P.; Hafezi, F.; Grimm, C. The Rpe65 Leu450Met variation increases retinal resistance against light-induced degeneration by slowing rhodopsin regeneration. J. Neurosci. 2001, 21, 53-58. [CrossRef] [PubMed]

77. Miranda, G.E.; Abrahan, C.E.; Politi, L.E.; Rotstein, N.P. Sphingosine-1-phosphate is a key regulator of proliferation and differentiation in retina photoreceptors. Investig. Ophthalmol. Vis. Sci. 2009, 50, 4416-4428. [CrossRef] [PubMed]

78. Castro-Rivera, E.; Ran, S.; Brekken, R.A.; Minna, J.D. Semaphorin 3B inhibits the phosphatidylinositol 3-kinase/Akt pathway through neuropilin-1 in lung and breast cancer cells. Cancer Res. 2008, 68, 8295-8303. [CrossRef] [PubMed]

79. Chen, H.; Tran, J.T.; Anderson, R.E.; Mandal, M.N. Caffeic acid phenethyl ester protects 661W cells from $\mathrm{H} 2 \mathrm{O} 2-$ mediated cell death and enhances electroretinography response in dim-reared albino rats. Mol. Vis. 2012, 18, 1325-1338.

80. Mandal, N.A.; Tran, J.T.; Saadi, A.; Rahman, A.K.; Huynh, T.P.; Klein, W.H.; Cho, J.H. Expression and localization of CERKL in the mammalian retina, its response to light-stress, and relationship with NeuroD1 gene. Exp. Eye Res. 2013, 106, 24-33. [CrossRef]

(C) 2018 by the authors. Licensee MDPI, Basel, Switzerland. This article is an open access article distributed under the terms and conditions of the Creative Commons Attribution (CC BY) license (http:/ / creativecommons.org/licenses/by/4.0/). 